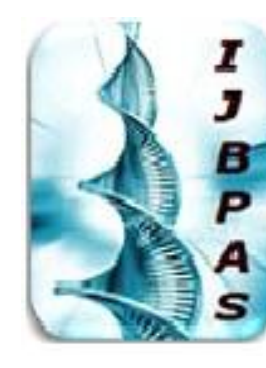

International Journal of Biology, Pharmacy and Allied Sciences (IJBPAS)

'A Bridge Between Caboratory and Q Qnende'

Www.ijbpas.com

\title{
SULPHA-TRANSFERASE (SULT-1A) GENETIC POLYMORPHISM AND RISK OF BREAST CANCER IN JORDAN
}

\section{MONA BUSTAMI ${ }^{1}$, NAGHAM HUSSEIN ${ }^{1}$, EYAD MALLAH ${ }^{1}$, ABDEL-ELLAH AL- SHUDIFAT $^{2}$, ISRAR SABRI $^{3}$, WALID ABU RAYYAN ${ }^{1}$, TAWFIQ ARAFAT ${ }^{4}$, AND $^{2}$ LUAY ABU-QATOUSEH ${ }^{{ }^{*}}$}

${ }^{1}$ Faculty of Pharmacy and Medical Sciences, University of Petra, Amman, Jordan ${ }^{2}$ Faculty of Medicine, The Hashemite University, Zarqa, Jordan

${ }^{3}$ Faculty of Pharmacy, Nursing and Health Professions, Birzeit University, Birzeit

West Bank, Palestine

${ }^{4}$ Jordan Center for Pharmaceutical Research, Amman, Jordan

*Corresponding Author: Faculty of Pharmacy and Medical Sciences, University of Petra, Airport

Road, Jordan. P. O. Box : 961343, Amman 11196-Jordan, Phone : +962(6) 5715546, Fax +962(6)

5715570; E Mail: labuqatouseh@uop.edu.jo; https://orcid.org/0000-0003-1551-2343

Received $15^{\text {th }}$ Aug. 2018; Revised 12 ${ }^{\text {th }}$ Sept. 2018; Accepted $14^{\text {th }}$ Oct. 2018; Available online $1^{\text {st }}$ Feb. 2019

https://doi.org/10.31032/IJBPAS/2019/8.2.4633

\begin{abstract}
Sulfotransferases (SULTs) family plays a significant role in the biotransformation of xenobiotics and endogenous carcinogenic and mutagenic compounds. Recent data identified various genetically polymorphic SULTs enzymes with significant variations in the enzyme activity. This study aimed to investigate the impact of SULT1A1 gene polymorphism and its potential risk on females with breast cancer in Jordan using a PCR-RFLP and Sanger Sequencing methods. The analysis showed that $24.7 \%$ of the patients and $25.3 \%$ of the controls were homozygous for the SULT1A1*1 allele (SULT1A1*1/SULT1A1*1) compared to $8.8 \%$ and $5.7 \%$ homozygous for the SULT1A $1 * 2$ allele $(S U L T 1 A 1 * 2 / S U L T 1 A 1 * 2)$ for patients and controls respectively. Most of the patients and controls were heterozygous for SULT1A1*1 allele (SULT1A1*1/SULT1A1*2) with rates of $66.5 \%$ and $69.0 \% 27$ in patients and controls respectively. In addition, the frequencies of
\end{abstract}


the mutant SULT1A $1 * 2$ allele were 0.42 and 0.4 in the patient and control groups respectively. No significant difference in genotype and allele distribution was noted between the breast cancer and control groups. The risk of breast cancer in individuals carrying the SULT1A1*2 allele was determined by combining the SULT1A1*1/SULT1A1*2 and SULT1A1*2/SULT1A1*2 genotypes. No association was observed 32 between SULT1A1 polymorphism and breast cancer incidence ( $\mathrm{P}=0.63$; OR, 0.93; 95\% CI, 0.68-1.26). 33 However, SULT1A1*2 allele was found to increase the risk of breast cancer by 1.26 -fold.

. Keywords: Polymorphism; breast cancer; SULT1A allele, DNA sequencing

\section{INTRODUCTION}

In human physiology, sulfotransferases (SULTs) are key factors in the conjugation of sulfate groups to a variety of endogenous and exogenous substrates, including many drugs, neurotransmitters, thyroid and steroid hormones and carcinogenic agents [1, 2]. SULTs are genetically polymorphic and are expressed in a wide variety of tissues, such as the liver, lung, brain, kidney, and platelets[3].There are four major families of SULTs: SULT1, SULT2, SULT4 and SULT6 with a 13 human cytosolic SULT isoforms have been identified [4]. The gene encodes the SULTs alloenzymes; SULT1A (SULT1A1*1 wild-type, SULT1A1*2, SULT1A1*3 and SULT1A1*4) which were mapped to chromosome 16p12.1-p11.2 with significant biochemical variations among their activities. This genetic polymorphism is remarkably important in case of a mutation in exon 7 at the nucleotide 46 of 638 (codon 213) resulted in a substitution of histidine by arginine (SULT1A1*2 allele) which is associated with less enzymatic activity and thermal stability compared with the wild-type allele (SULT1A1*1 allele) [5-6].

Breast cancer constitutes the most frequent female malignancies worldwide, accounting for 1.7 million cases and 521,900 deaths in 2012 worldwide [7]. In the Middle East region, it has been shown that the incidence rate for breast cancer has increased progressively over the last decade especially in younger aged patients [8-9]. Epidemiological variation of breast cancer among different ethnic populations was reported suggesting that genetic and environmental factors influence the development of this type of malignancies [10-11]. The relationship between genetic polymorphisms of SULT1A1 and several cancer types were investigated but results remain controversial [12-13]. This study investigated, for the first time, the 
relationship between the SULT1A1 Arg213His polymorphism and female breast cancer susceptibility in Jordan.

\section{MATERIALS AND METHODS}

\section{Population}

During August 2015 to Feb 2018, a total of 340 females (182 patients and 158 controls) were enrolled in this study. The breast cancer patients were referred to the breast care unit of prince Hamzah hospital (Amman). The patients were screened for breast cancer by mammograms and biochemical markers and confirmed by histopathology. Next generation sequencing was performed to confirm the presence of BRCA1/BRCA2 mutations by the specialty hospital laboratories (Amman). The control group consisted of females of ages above 20 years who are not presented with any clinical manifestation and who do not have a family history of breast cancer. Members of the study populations were informed with regards to the aims of the study. Epidemiological data were collected from the members using a designed standardized questionnaire. The study was approved by the Ethics Committee of Prince Hamzah hospital.

\section{Sample processing and maintenance}

Fresh blood samples were collected from each participant in EDTA tubes. A total of
$0.3 \mathrm{ml}$ of each sample were used while the remaining quantity was kept at $-80^{\circ} \mathrm{C}$ in case repeated testing is required. DNA extraction of the blood samples were performed using QIAamp Blood mini kit (Qiagen, Germany) according to the manufacturer's instructions. Whole blood was harvested and subsequently lysed by lysis solution. Treatment with proteinase $\mathrm{K}$ enzyme was performed for 30 minutes at $55^{\circ} \mathrm{C}$. Separation of DNA from proteins and cellular debris was performed using the spin columns and subsequently eluted in Elution buffer. The samples were stored at $-80^{\circ} \mathrm{C}$ until further analysis. Determination of DNA content was performed by measuring the optical density (OD) at $260 \mathrm{~nm}$ wavelength and the ratio between $\mathrm{OD}_{260}$ and $\mathrm{OD}_{280}$ using $\mathrm{UV}$ spectrophotometry (Biorad, Germany). The integrity of the extracted DNA was analyzed by $1 \%$ agarose gel electrophoresis stained by ethidium bromide [14].

\section{Genotyping of SULT1A1}

The presence of SULTA1 gene in the DNA isolated samples was detected using conventional PCR method as described by Arslan et al. 2009 with some modifications [15]. Consensus oligonucleotide primers (1A1 forward: 5'GTTGGCTCTGCAGGGTTTCTAGGA-3' and 1A1 reverse 5'- 
CCCAAACCCCCTGCTGGCCAGCACCC-3'

were preliminary used to amplify SULTA1

specific DNA of allele type. This was accomplished using oligonucleotide primers specific for the intron sequences flanking exon VII of the SULT1A. The amplified product was predicted to give a band of 333 bp in length, after analysis by gel electrophoresis, indicating positive results for SULTA1 gene. PCR reaction mixtures of $50 \mu 1$ were prepared by adding $2 \mu 1$ DNA to $0.4 \mu \mathrm{M}$ of each primer and $25 \mu \mathrm{l}$ of $2 \times$ PCR Master Mix (New England Biolab, UK). Initial denaturation was performed at $95^{\circ} \mathrm{C}$ for $5 \mathrm{~min}$, followed by 35 cycles of $94^{\circ} \mathrm{C}$ for $45 \mathrm{~s}, 55^{\circ} \mathrm{C}$ for $60 \mathrm{~s}$, and $72^{\circ} \mathrm{C}$ for $90 \mathrm{~s}$, with final extension at $72^{\circ} \mathrm{C}$ for $7 \mathrm{~min}$.

PCR-RFLP assay to detect the G: A transition that results in the Arg:His replacement in SULT1A1 was performed. PCR reaction products $(10 \mu l)$ were incubated with 1 unit of CutSmart HaeII (New England BioLab, UK) at $37^{\circ} \mathrm{C}$ for $20 \mathrm{~min}$ in a $50 \mu \mathrm{l}$ containing the appropriate enzyme reaction buffer supplied by the manufacturer. After digestion, heat inactivation of the enzyme was performed by incubation at $80^{\circ} \mathrm{C}$ for 20 min. Fragments were resolved on $3 \%(\mathrm{w} / \mathrm{v})$ agarose gels containing SYBR green and detected using UV transilluminator. The 333 bp fragment containing exon VII yielded two fragments of 168 and 165 bp after digestion with HaelI. Both SULT1A1*1/SULT1A1*1, and SULT1A1*1/SULT1A1*2 alleles were identified since digestion does not take place with DNA fragments amplified from SULT1A1 alleles harboring the CGC:CAC change at codon 213 , because this alters the restriction site recognition sequence for HaeII. All samples were tested in triplicate for reproducibility. Confirmation of the presence of mutations was performed by Sanger sequencing according to the following protocol: $1 \mu \mathrm{L}$ of the PCR products was mixed with $1 \mu \mathrm{M}$ of the sequencing primer (forward primer) and $1 \mu \mathrm{L}$ of the BigDye ${ }^{\circledR}$ Terminator $(\mathrm{v}$ 1.1/Sequencing Standard Kit), $3.5 \mu \mathrm{L} 5 \times$ buffer, and $13.5 \mu \mathrm{L}$ water in a total volume of $20 \mu \mathrm{L}$ for 20 enzymatic primer extension/termination reaction cycles according to the instructions of the manufacturer (Applied Biosystems, USA). After dye-terminator cleanup with Dye Ex 2.0-Spin columns (Qiagen, Germany), the reaction mixtures were loaded in an automated ABI 310 Genetic Analyzer for sequence analysis. Controls for sample adequacy were included in the sequencing kit and were used for each run. Internal control for PCR polymerase inhibitors were used by amplification of human B globin gene. 


\section{Statistical analysis}

Statistical Package for the Social Sciences (SPSS) release 20 (Chicago IL, USA) was used for the statistical analyses. Genotype and allele frequencies were tested by the Pearson's $\chi 2$ test. The statistical significance of the differences in SULT1A1 among the cases and controls was determined by the $\chi 2$ test. Probability values $<0.05$ were regarded as statistically significant [16]. Odds ratio and $95 \%$ confidence intervals (CIs) for breast cancer were calculated to study the relationship between the allele type and the incidence of breast cancer in the studied population.

\section{RESULTS}

Demographic characteristics of the patients and controls were summarized in Table 1. Mean ages of the patients and controls were $43.8 \pm 11.8$ years (range, 26-55) and 36.6 \pm 8.4 years (range, 20-50), respectively. No significant relationship was found between the patients and controls in terms of smoking status $(\mathrm{P}=0.29)$ and history of hormone replacement therapy $(p=0.33)$. SULT1A1 allele and genotype frequencies were indicated in Table 2. In the patient group, the frequencies of the homozygous wild-type genotypes $(S U L T 1 A 1 * 1 / S U L T 1 A 1 * 1)$, the heterozygous genotype $($ SULT1A1*1/SULT1A1*2) and the homozygous variant genotype $(S U L T 1 A 1 * 2 / S U L T 1 A 1 * 2)$ were $24.7,66.5$ and $8.8 \%$ respectively while in the control group, these frequencies were 25.3, 69.0 and $5.7 \%$ respectively.

The risk of breast cancer in individuals carrying the SULTIAI*2 allele was determined by combining the SULT1A1*1/SULT1A1*2 and SULT1A1*2/SULT1A1*2 genotypes. No statistically significant difference was observed between the patients and controls in comparison of the genotype combination ( $\mathrm{P}=0.63$; OR, 0.93; 95\% CI, 0.68-1.26). Similar results were observed when the smoker and non-smoker, and history of hormone replacement therapy populations were compared for genotype combinations.

Table 1: Epidemiological data of the patients and controls (n; number, SD;Standard Deviation)

\begin{tabular}{|c|c|c|}
\hline 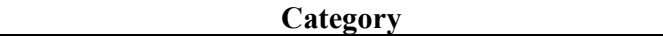 & Patients & Controls \\
\hline Total number & 182 & 158 \\
\hline $\begin{array}{c}\text { Age } \\
\text { Range } \\
(\text { Mean } \pm \text { SD) }\end{array}$ & $\begin{array}{c}26-55 \\
43.8 \pm 11.8 \\
\end{array}$ & $\begin{array}{c}20-50 \\
36.6 \pm 8.4\end{array}$ \\
\hline $\begin{array}{c}\text { Smoking Status n, (\%) } \\
\text { Smoker } \\
\text { Non smoker }\end{array}$ & $\begin{array}{c}38(21) \\
144(79)\end{array}$ & $\begin{array}{r}19(12) \\
139(88) \\
\end{array}$ \\
\hline $\begin{array}{c}\text { History of Hormone replacement therapy } n,(\%) \\
\text { Users for more than one month } \\
\text { Non-Users }\end{array}$ & $\begin{array}{c}14(8) \\
168(92) \\
\end{array}$ & $\begin{array}{c}8(5) \\
150(95)\end{array}$ \\
\hline
\end{tabular}


Table 2: Frequencies and risk estimation of SULT1A1 genotypes in breast cancer patients and health controls

\begin{tabular}{|c|c|c|c|c|}
\hline & Breast cancer $(n=182)$ & Controls $(n=158)$ & P value & $\chi^{2}$ \\
\hline \multirow{4}{*}{$\begin{array}{l}\text { Genotype frequency, n }(\%) \\
\text { SULT1A1*1/SULT1A1*1 } \\
\text { SULT1A1*1/SULT1A1*2 } \\
\text { SULT1A1*2/SULT1A1*2 }\end{array}$} & & & & \\
\hline & $45(24.7)$ & $40(25.3)$ & \multirow[t]{3}{*}{0.55} & \multirow[t]{3}{*}{1.192} \\
\hline & $121(66.5)$ & $109(69.0)$ & & \\
\hline & $16(8.8)$ & $9(5.7)$ & & \\
\hline \multirow{3}{*}{$\begin{array}{c}\text { Allele frequency, n }(\%) \\
\text { SULT1A1*1 } \\
\text { SULT1A1*2 }\end{array}$} & & & \multirow{3}{*}{0.63} & \\
\hline & $211(58)$ & $189(59.8)$ & & \multirow[t]{2}{*}{0.237} \\
\hline & $153(42)$ & $127(40.2)$ & & \\
\hline
\end{tabular}

\section{DISCUSSION}

Breast cancer is so far, the most frequent type of malignancies among women worldwide. The rates of breast cancer have been shown to be variable among ethnic groups [17]. Recent data showed that the incidence is increasing in the Middle East [18, 19]. SULT1A is considered as a phase II enzyme. That also bio-activates various carcinogenic agents which are related to the development of different types of cancers [20]. Recent evidence suggests a potential role of the genetic polymorphisms in xenobioticmetabolizing enzymes in increasing the susceptibility of individuals to cancer [21, 22]. In this context, different genetic background in the SULT1A1 would importantly affects the risk estimates associated with the development and prognosis of breast cancer. It is believed that the development of breast cancer depends not only on germ line mutations of BRCA1/BRCA2 genes, but also on several factors including age, tobacco use, hormone therapy and ethnicity $[23,24]$. The frequencies of the $S U L T 1 A 1 * 2$ allele differ ranging from 5 to $32 \%$ among ethnic populations $[4,25]$. In the present study, the frequency of this allele in the control group was $40.2 \%$ that is higher than the frequency in Turkish, Chinese, Taiwanese and Koreans while close to the frequency reported for Caucasians [4, 26]. In regards to the SULT1A1 genotypes and alleles, no statistically significant difference between the patients and controls was observed in this study. The presented study showed clearly that the polymorphism of SULT1A1 gene did not have a significant relationship with female breast cancer although the presence of SULT1A1*2 allele increased the risk in the patient's group. This is in agreement with a study conducted in Turkey in cases of prostate cancer, which also suggested no role of age and smoking as factors in the allelic polymorphism of SULT1A gene [16]. In contrast, Palli et al., 2013 revealed that BRACA2 male breast cancer is highly associated with SULT1A1 low enzymatic activity and accordingly to environmental 
exposure variations [27]. Roupret et al., 2007 also found a significant association between the $S U L T 1 A 1 * 2$ allele and risks for cancers of the urinary tract [28]. In addition, the risk of smoking and use of hormone replacement in the patients with breast cancer was not associated with the allele variation and the risk of cancer development in the present study. Since ethnicity cannot be excluded as a factor for these controversial results, other related factors including the exposure to geographical variations might be less involved in the development of breast cancer and more concern should be placed on the genetic variation of BRCA1/BRCA2 in patients with breast cancer. Although the results of our study support the fact that the SULT1A1 polymorphism does not play a role in breast cancer susceptibility, the current study is the first to report the allele frequencies of SULT1A gene in Jordan population with breast cancer. Hence, more work is needed for better understanding of the relationship between the SULT1A1 polymorphism and breast cancer especially with regards to the environmental exposure to specific carcinogens in larger population studies.

\section{CONCLUSION}

SULT1A1 polymorphism does not play a role in breast cancer susceptibility in Jordan.
Different risk factors can be associated with the increase risk of breast cancer including genetic variability of BRCA1/BRCA2 polymorphism.

\section{ACKNOWLEDGEMENTS}

This study was supported by the Deanship of scientific research (project number 4/4/2017) University of Petra-Jordan. The authors wish to thank staff of University of Petra Pharmaceutical Center (UPPC), Jordan Center for Pharmaceutical Research (JCPR) and prince Hamzah Hospital for providing necessary facilities for conducting this research. In addition, the authors are thankful for Specialty Hospital and Al-Faiha Company for their technical support.

\section{REFERENCES}

[1] Falany CN. Enzymology of human cytosolic sulfotransferases. FASEB J.11,1997, 206-16.

[2] Glatt H. Sulfotransferases in the bioactivation of xenobiotics. Chem Biol Interact. 129,2000, 141-70.

[3] Pereira WO, Paiva AS, Queiroz JW, Toma L, Dietrich CP, Nader HB, Jerônimo SM. Genetic polymorphism in the sulfotransferase SULT1A1 gene in cancer. Cancer Genet Cytogenet.197(60),2005,160:55.

[4] Glatt H, Engelke CE, Pabel U, Teubner W, Jones AL, Coughtrie 
MW, Andrae U, Falany CN, Meinl

W. Sulfotransferases: genetics and role in toxicology. Toxicology letters. 15(112), 2000, 341-8.

[5] Raftogianis RB, Wood TC, Otterness DM, Van Loon JA, Weinshilboum RM. Phenol sulfotransferase pharmacogenetics in humans: association of commonSULT1A1alleles with TS PST phenotype. Biochemical and biophysical research communications. 239(1), 1997 298-304.

[6] Nowell S, Ambrosone CB, Ozawa S, MacLeod SL, Mrackova G, Williams S, Plaxco J, Kadlubar FF, Lang NP. Relationship of phenol sulfotransferase activity (SULT1A1) genotype to sulfotransferase phenotype in platelet cytosol. Pharmacogenetics and Genomics. 10(9), 2000,789-97.

[7] Siegel RL, Miller KD, Jemal A. Cancer statistics, 2015. CA: a cancer journal for clinicians. 65(1), 2015,529.

[8] Missaoui N, Jaidene L, Abdelkrim $\mathrm{SB}$, Abdelkader $\mathrm{AB}$, Beizig $\mathrm{N}$, Yaacoub LB, Yaacoubi MT, Hmissa S. Breast cancer in Tunisia: clinical and pathological findings. Asian Pac J Cancer 12(1), 2011,169-72.

[9] Laraqui A, Uhrhammer N, El Rhaffouli H, Sekhsokh Y, LahlouAmine I, Bajjou T, Hilali F, El Baghdadi J, Al Bouzidi A, Bakri Y, Amzazi S. BRCA genetic screening in Middle Eastern and North African: mutational spectrum and founder BRCA1 mutation (c. 798_799delTT) in North African. Disease markers. $2015 ; 2015$.

[10] Cavalieri EL, Rogan EG. The etiology and prevention of breast cancer. Drug Discovery Today: Disease Mechanisms. 9(1-2), 2012, e55-69.

[11] Foulkes WD. Inherited susceptibility to common cancers. New England Journal of Medicine. 359(20), 2008, 2143-53.

[12] Hung RJ, Boffetta P, Brennan P, Malaveille C, Hautefeuille A, Donato F, Gelatti U, Spaliviero M, Placidi D, Carta A, Scotto di Carlo A. GST, NAT, SULT1A1, CYP1B1 genetic polymorphisms, interactions with environmental exposures and bladder cancer risk in a high-risk population. International Journal of Cancer. 110(4), 2004,598-604. 
[13] Arslan S, Silig Y, Pinarbasi H. Sulfotransferase 1A1 Arg213His polymorphism and prostate cancer risk. Experimental and therapeutic medicine. 2(6), 2011,1159-62.

[14] Pachouri SS, Sobti RC, Kaur P, Singh J, Gupta SK. Impact of polymorphism in sulfotransferase gene on the risk of lung cancer. Cancer genetics and cytogenetics. 171(1), 2006, 39-43.

[15] Abu-Qatouseh LA, Sabri I,Alkhatib I, Atwa E, Arafat, T. Detection of High-Risk Human 224 Papillomavirus Genotypes 16 and 18 in Head and Neck Squamous Cell Carcinomas in Jordan. APJCP 18,2017, 1337-41.

[16] Arslan S, Silig Y, Pinarbasi H. An investigation of the relationship between SULT1A1 Arg213His polymorphism and lung cancer susceptibility in a Turkish population. Cell Biochemistry and Function: Cellular biochemistry and its modulation by active agents or disease. 27(4), 2009,211-5.

[17] Fang C, Wei XM, Zeng XT, Wang FB, Weng $\mathrm{H}$, Long $\mathrm{X}$. Aberrant GSTP1 promoter methylation is associated with increased risk and advanced stage of breast cancer: a meta-analysis of 19 case-control studies. BMC cancer. 15(1), 2015, 920.

[18] Azim HA, Ibrahim AS. Breast cancer in Egypt, China and Chinese: statistics and beyond. Journal of thoracic disease. 6(7), 2014,864.

[19] Saggu S, Rehman H, Abbas ZK, Ansari AA. Recent incidence and descriptive epidemiological survey of breast cancer in Saudi Arabia. Saudi medical journal. 36(10), 2015, 1176.

[20] James MO, Ambadapadi S. Interactions of cytosolic sulfotransferases with xenobiotics. Drug Metab Rev. 45, 2013,401-14.

[21] Umamaheswaran G, Kumar DK, Adithan C. Distribution of genetic polymorphisms of genes encoding drug metabolizing enzymes \& drug transporters-a review with Indian perspective. The Indian journal of medical research. 139(1),2014,27.

[22] Mota P, Silva HC, Soares MJ, Pego A, Loureiro $\mathrm{M}$, Cordeiro $\mathrm{CR}$, Regateiro FJ. Genetic polymorphisms of phase I and phase II metabolic enzymes as modulators of lung cancer susceptibility. Journal 
of cancer research and clinical oncology. 141(5), 2015, 851-60.

[23] Donenberg T, Ahmed H, Royer R, Zhang S, Narod SA, George S, Akbari MR, Ali J, Hurley J. A Survey of BRCA1, BRCA2, and PALB2 mutations in women with breast cancer in Trinidad and Tobago. Breast cancer research and treatment. 159(1), 2016, 131-8.

[24] Lai KN, Ho WK, Kang IN, Kang PC, Phuah SY, Mariapun S, Yip $\mathrm{CH}$, Taib NA, Teo SH. Characterization of BRCA1 and BRCA2 variants in multi-ethnic Asian cohort from a Malaysian casecontrol study. BMC cancer. 17(1), 2017,149 .

[25] Coughtrie MW, Gilissen RA, Benedicte SH, Richard C, FRYER AA, JONES PW, BAMBER DE. Phenol sulphotransferase SULT1A1 polymorphism: molecular diagnosis and allele frequencies in Caucasian and African populations. Biochemical journal. 337(1), 1999, 45-9.

[26] Lee SJ, Kim WY, Jarrar YB, Kim YW, Lee SS, Shin JG. Single Nucleotide Polymorphisms in
SULT1A1 and SULT1A2 in a Korean population. Drug metabolism and pharmacokinetics. 28(4), 2013, 372-7.

[27] Palli D, Rizzolo P, Zanna I, Silvestri V, Saieva C, Falchetti M, Navazio AS, Graziano V, Masala G, Bianchi S, Russo A. SULT 1A1 gene deletion in BRCA 2-associated male breast cancer: a link between genes and environmental exposures?. Journal of cellular and molecular medicine. 17(5), 2013, 605-7.

[28] Rouprêt M, Cancel-Tassin G, Comperat E, Fromont G, Sibony M, Molinié V, Allory Y, Triau S, Champigneulle J, Gaffory C, Larré S. Phenol sulfotransferase SULT1A1* 2 allele and enhanced risk of upper urinary tract urothelial cell carcinoma. Cancer Epidemiology and Prevention Biomarkers. 16(11), 2007, 2500-3. 